\title{
The Role of the Head of State on National Security Issues in Presidential Democracies - The USA Case
}

\author{
Murat Jashari ${ }^{1}$, Behar Selimi ${ }^{2}$ \\ ${ }^{1}$ Professor of Constitutional Law, Prishtina University, Kosovo \\ ${ }^{2}$ Former General Director of Kosovo Police, Lecturer of Political Science, UBT College, Kosovo \\ Correspondence: Behar Selimi, Former General Director of Kosovo Police, Lecturer of Political Science, UBT College, \\ Kosovo.
}

Received: May 8, 2017

doi:10.11114/ijsss.v5i7.2401
Accepted: May 27, $2017 \quad$ Available online: June 7, 2017

URL: https://doi.org/10.11114/ijsss.v5i7.2401

\begin{abstract}
American democracy continues to be one of the most stable democracies in the world and the model followed by many countries of the world. The practice of presidential governance based on the principle of 'checks and balances' of powers, has shown that the head of state should have sufficient executive powers to preserve and guarantee the democracy, especially in the field of defense and security. Furthermore, in circumstances of threats to national security, its powers can and should set a "balance" of powers in favor of the executive power, while not ignoring "control" of other powers over the executive power. It is precisely the power of the US president in the field of defense and security that is the subject of the treatment of this paper, which will be addressed beyond classical analyses based solely on his powers as commander in chief of the army. So, we will try to analyze all the powers, which in one way or another, can affect the defense and security policies.
\end{abstract}

Keywords: president, commander, congress, National Security Council, executive order

\section{Introduction}

The presidential system of the United States, being the first of its kind and specific, continues to be the best example of a comparative study of the powers of the president in the presidential governance in many areas, including the field of defense and security. All other countries ( 40 of them) applying the concept of presidential governance, mostly tried to imitate this system to the level of degradation.

According to the US Constitution (Article 2) executive power is exercised by the president, who is elected for a term of four years with the possibility of reelection for a second term. In exercising his responsibilities, the President is assisted by the Vice President, who was also elected with the president in the election process of electors (electorate votes).

Although the drafters of the Constitution were careful to see that the president has a strong constitutional position, however the US constitution has not many provisions regulating his position. One of the best connoisseurs of presidential power and adviser to three presidents (Truman, Kennedy and Lyndon Johnson), Professor Richard Neustadt had noticed earlier that "presidents enjoy much less formal constitutional power than necessary to achieve the expectations that weigh on them in modern times. The key to strong leadership lies not in the formal power, but in the skills, temperament, personal experience and personal skills to exploit these qualities to strengthen his reputation and prestige." (Presidential Studies Quarterly 29, no. 4,p850). The professor's conclusion is based on his theoretical studies, and rather in his scientific observations during his time as presidential adviser. The practice of US presidential behavior, skills and personal abilities of each president until nowadays support this finding. Every president has provided his own position with the powers and opportunities that the other or his successor did not have continuing to deepen and expand powers established by the predecessor. So today there is a strong American president, who has sufficient authority to respond to the expectations of the American electorate, and beyond. Especially the so-called "immanent rights inherited powers" represent the basis of sufficient flexibility to add powers in all spheres federal executive power. These rights imply the rights that are the epitome of office or function and do not derive from outside or from any other body sufficient (Black's Law Dictionary 1968, p. 921.)

These rights derive from Article 2 of the Constitution, which leaves no doubt as regards the executive power, especially 
in Paragraph 3 according to which "the president must take care that the laws be implemented faithfully" including the constitutional determination for the President as the supreme command of the military. Article 2 of the US Constitution has only four paragraphs, which defined the entire presidential power and his choice. According to this article, the President is the chief executive of state or head of state respectively. He is the Commander in Chief of the Army and Navy of the United States and the Territorial Defense Forces of individual states when they are mobilized in the service of the United States. He may seek written opinions and advice from any of senior officials of any executive branch on any issue that has to do with their field of activity. He is also entitled to seek a stay of execution of sentence or remission of punishment for violation of the laws of the United States, except in cases of lawsuits. He is entitled on the advice and consent of the Senate to sign treaties, provided that two thirds of senators attending give their consent. President appoints, on the advice and consent of the Senate, ambassadors, special envoys and consuls, judges of the Supreme Court and all other senior officials of the United States. The Constitution authorizes Congress so that the President can by law entrust to it the appointment of lower officials, court judges or heads of departments. The President is entitled to make appointments to fill all vacancies which may have arisen during the time the Senate is in recess and these appointments are valid until the end of the next coming session.

Occasionally the President informs the Congress on the state of the country submitting a review of measures, which in his judgment are necessary and useful. In exceptional cases, he may call meetings of both houses or one of them and if they cannot agree on the time of meeting, he can postpone it for a time he considers appropriate. This same article under Paragraph 3, represents the basis of immanent or inherent power under which the president "should take care of the correct implementation of laws".

\section{The President and National Security Council}

The primary presidential body, which carries the entire burden of development and implementation of national security policy in the US is the National Security Council, which is under the authority of the President. The establishment of the council was the result of the presidential efforts for better coordination of US security institutions in order to increase efficiency especially after the Japanese attack on "Pearl Harbor". The attack had caught by surprise the entire defense and security apparatus of the US and consequently had caused great damage to the people and military technology, but also to geopolitical project of the US. Presidency's efforts to reorganize the security apparatus were joined by the Congress, which was disgruntled with the style of "personalization of security policies management" during President Roosevelt's administration (Whittaker, Alan G. Brown, Shannon A. Smith, Frederick C. \& McKune, Elizabeth ,2011). The Congress intended to create a formal structure of an organization, which would include sectors of operational security and their political leadership in order to better coordinate an intelligent anticipation of threats, better financial defense planning and to offer competent advice to the President before taking decisions. This attempt by the Congress to have an executive role in decision-making on security issues resulted in success in 1947 when Congress passed the Law on the National Security Council. This was in the days of President Truman, who was not pleased with the efforts by Congress to limit presidential power in security matters and therefore was reluctant to implement the law. He even refused to attend at the beginning the meetings of the Council. He sent his Secretary of State to the meetings instead. It was only after the Korean War, when he began to appreciate and utilize the services of the council, whose main task is the creation and supervision of the implementation of security policies on behalf of the president.

The Council consists of the main actors of national security, and therefore is indeed the main decision making body, although decisions belong personally to the President. The Council is chaired by the President and is composed of the Vice President, Secretary of State, Secretary of Defense, Energy Secretary, Director of the Central Intelligence Service (CIA), Director of National Intelligence (DNI) director of the Office of National Drug Control, Army Chief of Staff, Secretary of Homeland Security and the President's Security Adviser. There are also other participants dealing with management policy approved by the president. After approval of the policy recommendations, or after the decisions signed by the president, they are transformed into concrete plans of measurable security objectives for all departments and national security agencies (M.Destler,1986). So the composition of the Council and the type of policies recommended by the Council show the real power of the President in both security policy making, as well as their implementation.

\section{President's Relation with Congress}

Relations between the US President and Congress are mainly relations of coordination and cooperation rather than relations of subordination, as is the case in pure parliamentary republics. Reports of subordination are an exception and they can arise in cases of use of the suspensive veto by the President, or when Congress uses the mechanism of impeachment respectively against the President. For most of the constitutional implementations of competencies of both powers cooperation between them is needed. The founders of the state saw to it that the two powers be strictly separated, balanced and controlling each other and therefore obliged to cooperate. 
Every president tries to implement his own program and for this he needs legislative and financial support from the Congress. Therefore he tries to have relations of ongoing cooperation with both the congressmen and senators either individually or as a whole.

The US Constitution does not entitle him with the right of proposing laws, but his obligatory appearance from time to time to inform the Congress about the state of the country provides him with an opportunity "to propose measures that he deems necessary and useful",( US Constitution, Article 2, Paragraph 3) within which he can propose the legislation needed to support the fresh measures that he requires. In the presidential practice several ways of President's cooperation with politically powerful congressmen or senators and with groups of them are known. Individual meetings at the White House, joint trips, promises to support their re-election, etc., are just some of the forms through which the president gets legislative and political support of the Congress to solidifying his policies. ... He may even appear in public for support from citizens, who then put pressure on Congress to support the presidential agenda. This way of the President's influence is dependent of what Professor Neutstadt called "the power of persuasion", which in turn depends on the abilities and skills of the personality of the elected president,( Robert Y. Shapiro,2000).

\subsection{Presidential Veto}

The presidential veto is the most powerful means of influence of the executive against the legislative power. According to the US Constitution (Article 1, paragraph 7) each bill issued by the House of Representatives and the Senate before it becomes law is submitted to the President of the United States. And not only the draft-bills, but also resolutions, orders, decisions or votes, which are required to be voted in both houses of Congress, should be sent to the President for signature. If he accepts, then he signs them. Otherwise he turns them back together with his remarks to the Chamber that passed them, which takes note of the remarks in detail in its protocol and amends them. If after such review, two-thirds of that Chamber do not have objections to the approval of the bill, it is sent along with the president's remarks to the other chamber, where it is examined in the same way and with the approval of two-thirds of this chamber turns into law. But in all these cases the votes of both houses shall be determined by counting the pros and cons. Names of the persons voting for and against the relevant are recorded in the of each chamber.

The President may entirely ignore the bill by not responding with consent or by refusing it within the ten days limit. In such cases, i.e. if a bill is not submitted by the President within ten days (excluding Sundays) from the day it has been presented to him, it takes effect the same as if it had been signed by him, with the exception of those cases where the postponement of its works the Congress prevents the submission of the draft, causing it not be recognized as law. In cases when the president refuses to sign the bill, using regular suspension veto, the bill is returned to Congress, or its relevant chamber respectively, which prepared the draft and which may initiate proceedings against the President's veto. The President's veto can be overturned if $2 / 3$ of the members present and voting of the House of Representatives and $2 / 3$ of the members present and voting of the Senate.

Meanwhile the pocket veto is another opportunity for the president to prevent a bill from becoming a law. This right may apply if after the delivery of the bill in the next ten days Congress is not in session, upon which the president does not sign the law having the pretext that there is no one to reply to and therefore he simply does not signed it and it cannot become a law.

The importance of the constitutional institution of the president's veto is also confirmed by the fact that "since the establishment of the federal government in 1789, 37 of 44 US presidents have used their veto power 2566 times. Only 110 times the Congress was able to achieve a qualified majority of two thirds in both houses to topple presidential suspension vote. Of all these cases, 1066 or $41.5 \%$ were rejections through the "pocket veto", namely laws not signed when Congress was in recess while the ten-day time limit not including Sundays was running (http://www.senate.gov/ reference/reference_index_subjects/Vetoes_vrd.htm.)

There are many cases of the use of suspensive veto relating directly to national security policies. For illustration we will mention just a few cases that clearly exemplify my case about the importance and power of the presidential veto on security issues.

\subsection{The Case of President Nixon's Veto}

The case of President Nixon's veto is a clear example of the use of the suspensive veto and its override by the Congress regarding Resolution of Authorizations for War adopted by the Congress on 7 November 1973. According to the US Constitution Article 2.8, the authority for declaring war and the establishment and support of the armed forces, National Guard mobilization, and especially the financing of defense is the exclusive competence of the Congress. But on the other hand the President is the Supreme Commander of the armed forces and the sole bearer of executive power. This situation has led presidents to use the right of supreme command and authorize the use of armed force without the consent of Congress. The American military involvement in the Korean and Vietnam wars was exactly a commitment 
without congressional authorization. ... President Nixon had authorized the bombing in Cambodia during the Vietnam War, which had worried Congress. Therefore representatives of both chambers decided to adopt a resolution by which the decision about war and peace was the result of "joint justification" by both powers that would clearly determine the decision-making procedure (“War Powers Resolution", P.L. 93-148).

President Richard Nixon had used the right of veto against this resolution, but Congress was able to it approve by $2 / 3$ again and the resolution again to take the character of the law on emergency situation. What does actually this enforced resolution contain?

According to this resolution, paragraph 2, the President may authorize the use of armed forces abroad only if war has been declared by the Congress, unless Congress has specifically authorized or if emergency conditions arise as a result of an attack on US territory, its properties or to the armed forces.

The resolution demanded that the president, if compelled by extraordinary circumstances, authorize the use of armed force, should notify Congress within 24 hours and report regularly on the progress of operations and the status of forces. It expressively demands that reports have to be submitted whenever Congress requires it, in no way less than once in 6 months. After the first reporting the President is required within 60 days to stop the use of the armed forces, unless Congress in the meantime declares a state of war, if he extends the time limit by law or if Congress itself is unable to convene due to security circumstances. The 60-day deadline may be extended by the President for 30 days if deemed necessary for the security of the armed forces themselves. Paragraph 5 is particularly limiting, according to which Congress may order the withdrawal of the armed forces through a special resolution. However, the Federal Court of the United States in 1983 reduced this limitation, demanding that such a resolution should be adopted by a qualified majority of 2/3 in each chamber separately and that the resolution shall be sent to the president for signature.

On the basis of this Resolution even to this day, whenever there is a need for the use of the armed forces, Congress and the President enter the lengthy process of debate and contentions in efforts to defend the priority in the use of constitutional powers one (President) invoking on the exclusive executive authority executive as Supreme Commander of the armed forces and other (Congress) on the exclusive authority to declare a state of war.

One of the characteristic cases and of interest to our citizens is President Clinton's order authorizing the US Air Force for air strikes against Serbian military forces in Kosovo, including its supporting infrastructure to stop genocide against ethnic Albanians. According to the War Powers Resolution of 1973 the President should have asked for the consent of Congress for a such an action or at least should have notified the Congress within 24 hours of the order issued after 60 days, and if Congress did not authorize the intervention, he would have to order the withdrawal of US soldiers from the operation in question.

President Clinton did not seek consent but he rather notified Congress for the start of military intervention on 26 March 1999, namely two days after the airstrikes had begun. A day before the intervention the US Senate had adopted a non-binding resolution which authorized the attacks, but that resolution was not passed in the House of Representatives for consideration and therefore it was not considered a legal authorization under War Power Resolution. President's order for military intervention, was challenged in the Federal Court by a group of 17 representatives, led by Republican Congressman Tom Campbell, but their claim was rejected on the grounds that the President had the authority upon the fact that Congress had authorized a budget for respective military engagement, hence it had legitimized the intervention. A similar and equally difficult President-Congress relationship occurred in the case of Bosnia.

\subsection{Signing Statement}

Signing statement is another way of the President's influence over the legislative power. It is implemented with the signing of the bills by the President. It is a middle way between the rejection of the bill by suspension veto and signing it without reservations (with no say, as people would put it.) So the bill is signed and the President's statement attached in which he expresses his views on the law, i.e. reservations on certain parts of the law. On the US constitutional right no suspensive veto can be partially applied only on certain parts of the law, but rather on its entirety. Therefore the implementation of the signing statement is the most common alternative for the President to use, which allows for the law to be adopted in its entirety, though reservations may appear in the implementation of certain parts. There are numerous examples of the use of this political institution by almost all US presidents. In the history of the use of the signing statement, President George Bush Junior was the most frequent user of this option by which he made space for selective implementation of legal provisions, especially bills containing national security issues. Although in regard to the number (161) of use he is not much different from other presidents, his contesting comments upon the signing of the law numbered as many as 1000 provisions on different laws of which he showed no enthusiasm in regard to their application as he considered them to be contrary to the principle of separation of powers and as interference in his powers as sole bearer of the executive power, especially as Supreme Commander of the armed forces. 


\section{Appointment and Dismissal of Senior State Officials}

The US President appoints all his cabinet secretaries and they respond only to him. This includes the Secretary of Defense and the Secretary of State, who is an important factor in the creation and implementation of national security policy. Of course for their appointment, but not for their dismis sal, Senate's consent is required.

For more, the President "... shall have Power, by and with the Advice and Consent of the Senate, to make Treaties, provided two thirds of the Senators present concur; and he shall nominate, and by and with the Advice and Consent of the Senate, shall appoint Ambassadors, other public Ministers and Consuls, Judges of the supreme Court, and all other Officers of the United States, whose Appointments are not herein otherwise provided for, and which shall be established by Law: but the Congress may by Law vest the Appointment of such inferior Officers, as they think proper, in the President alone, in the Courts of Law, or in the Heads of Departments. The President shall have Power to fill up all Vacancies that may happen during the Recess of the Senate, by granting Commissions which shall expire at the End of their next Session." (Article 2,Section 2)

So by constitutional definition, the President is the main actor in the selection of officers, who shall serve him for the realization of the program on behalf of which he has gained legitimacy both as head of state and head of government. But the president is not the only factor. Most of the officers can be appointed only if he gets the consent of the Congress, or Senate respectively. The President originally proposes (nominates) candidates, which are then subject to examination and voting process by the Senate. Consent is deemed granted if the proposed nominations receive a simple majority, i.e. a majority of senators present and voting. This process will undergo about 800 senior officials, secretaries of departments, their subordinates, heads of departments, heads of agencies, etc., out of about 3000 officers to be appointed independently of Congress and are serving fully Presidential agenda according to the President's will.

Officials proposed by the President are subject to a parliamentary verification process including e valuation of candidate biographies, profiles of their political or professional credibility among the people. They can refuse nominations only if, as Alexander Hamilton envisaged, they have "special and strong reasons for rejection" (Alexander Hamilton, John Jay \& James Madison,2010). This phrase has not been further explained by Hamilton or by other authors of the constitution, therefore senators upon rejection of nominations are based on different evaluations and on the basis of their personal views considering them as specific or compelling reasons . In general these reasons, based on experience to date, can be divided into four types. These groups or categories of reasons are as follows: illegal or unethical conduct, conflict of interest, qualifications and public policies.

There is a constant "battle" between the President and his claims to power less restricted in his right for the selection of senior officials and Congress with its claims that the Constitution asks for them to be considerate in the case of appointments. Right now it seems that the President is failing to win support in Congress and therefore re duce the number of positions for which the consent of the Senate is required. The Law for efficiency and simplification of procedures of appointments of 2011 describes this list of long positions of undersecretaries, assistants, secretaries, department directors and deputy directors of different sectors including defense and intelligence departments, (Public Law 112 - 166, Presidential Appointment Efficiency And Streamlining Act Of 2011).

\section{President as Supreme Commander of Armed}

US President under the Constitution is the Supreme Commander of the Armed Forces, the Navy and the popular militia of several states when called to serve the United States (Article 2, Paragraph 2 of US Constitution). This term includes the supreme control over military operations during wartime, not only in strategic and tactical terms, but also in political and international aspect (Black's Law Dictionary,1968). In peacetime, he oversees most senior military and intelligence services, who he also appoints with the consent of the Senate. He is also the authority which dismisses them without the Senate's consent. As for some time now the US continues to be active in international security politics with military forces operating in four continents, it can be said that the President is always the supreme authority of the military commitments and special operations services of intelligence services engaged in war. The Chief of Staff of the US military and intelligence director are subordinates to the president and responsible for operational aspects, while the Defense Secretary and the Secretary of State are responsible for political aspects of national security strategy.

Executive Privileges are another powerful mechanism for the President, through which he can classify information dealing with national security, which believes fall in the protection and security of the country. So the President cannot hide information or refuse to present the information to Congress, the courts or the public. These rights are not recognized by the Constitution, but supported by a precedence established by the Supreme Court in the trial of the case of "Watergate", in which the prosecutor demanded that President Nixon delivers personal communication materials with his associates as the prosecution claimed that those materials would prove that the President was aware of the illegal intervention of his men at the Headquarters of the Democratic Party in order to influence the election results of the elections that were on the verge. Finally the President was forced to submit recordings of communications by a 
Supreme Court decision which acknowledged that the President is authorized to keep secrets and not show them to other branches of government, but only in some areas dealing with and not national security but not these materials, which are part of communications within inter-party battle and in view of the presidential elections. This Court decision is used today as the sole legal basis for the protection of so-called executive privileges. There are at least four areas in which the executive claims he has the right to invoke executive privileges: a) his communications in general and his associates in particular; b) consultation process; c) issues of defense, security and foreign affairs; d) in a case under ongoing investigation (Rozell, Mark, 2012)

These privileges have been used by most presidents including the presidents of our time. In most cases they were based on the justifications in the name defense and security and foreign policy. The administration of President Bush (Junior) is recognized as one of the US administrations that mostly used this kind of privileges by classifying millions of information relating to the interception of citizens American and foreign nationals, arrest and detention on different bases all over the world of about 9,000 terrorism suspects, etc. There were voices for the "executive privileges" to be regulated by law, yet they are still considered to be self-evident part of the post of presidential authority.

One of the special powers exercised by the president within his function as supreme commander of the armed forces and head of the executive is his authority for the management of emergency situations whatsoever. For more he is the only authority bearing responsibility for protecting the state and people challenged by emergencies caused by natural or human disasters or possible hostile attacks.

\subsection{Powers in Emergency Cases}

Although the Constitution does not expressly define powers in emergencies, the President on the basis of his constitutional status as chief executive and head of state, and as supreme commander of the armed forces, is the sole executive authority with the task of protecting the country, therefore it is his task to respond to emergency situations in which the country's security and constitutional order, namely to "catastrophic emergencies, namely incidents, regardless of locations where they occur and their large scale consequences, damages and disruptions affecting the US population, infrastructure, environment, economy, or government functions " (Presidential Order no.51, 9 May 2007)

Competences in emergency cases are regulated by many presidential directives, executive orders and the law for emergencies and civil protection law. The latter, adopted under President Truman (1950), leaves the civil protection in emergency situations leaves under the jurisdiction of the states, establishing a federal department as well to serve as a coordinating body of the US federal units (i.e. with their governments) and representing the authority of the President's office. In addition, the law on state of emergency is one that more closely regulates the authority of the President as well as his duties in relation to the Congress. The President is obliged to notify Congress to declare a state of emergency and to report from time to time. The state of emergency must be supported by a Congress resolution, namely its two chambers, may it mast as long as stipulated in the decree of promulgation, i.e. until the President or Congress decide otherwise. If the President does not ask for an extension of the emergency situation it automatically ceases when a year from the date of announcement has passed (National Emergency Act,1976)

As mentioned above, the US constitution does not regulate at all the either the power or emergency situation, and one may say that the above-mentioned acts do not even closely regulate decision-making, leadership or managing of measures dealing with such a condition, and it fails to define the structure of the response. All these aspects are regulated mainly through executive orders and presidential directives based on philosophical and constitutional views according to which, "in emergency circumstances, the executive. i.e. President should use the right of wide discretion in the face of emergencies, despite the fact that the legislature has not established relevant legislation (Locke,Jon,1947). So the practice of presidential governance has created a precedence called "Locke's Prerogatives" on the basis of which the President in the circumstances of emergencies and when there is no possibility to soon call on the Congress can and should act in the absence of relevant legislation, even against it, in order to protect the public interest (Lois Fisher: The White House Transition Project, Reports 2009-06). President Theodore Roosevelt's interpretation, which is in full compliance with the Locke's view, left its mark on the presidential political practice, but also in presidential scientific doctrine, when writing and analyzing the power of the US president. According to him, "the executive power can be limited to specific constitutional limitations or legal restrictions imposed by acts of Congress." Hence, he thinks that the President enjoys free discretionary power to use measures that are necessary in response to the nation and which are not specifically prohibited by the constitution or by law. And this is "not only a right but also a duty" (Roosevelt, Theodore, 1913).

\section{Conclusions}

In the American case, the President is sufficiently coated with executive power as to be the main factor on the defense and security issues. His powers as commander in chief, the power of appointment of key officials of defense and security, the right of suspensive and pocket veto, and the signing statement of laws with executive privileges to define 
state secrets, are only some of the presidential governance mechanisms that serve to encourage a strong president on all executive matters, especially those of national security. Especially the so-called "Inherent Powers" represents the basis of sufficient flexibility to add power in all the executive spheres of federal power. These rights include the rights standing as epitomes of the office or function and do not derive from outside or from any other body.

However in the American presidential democracy the President is sufficiently controlled and the majority of defense and security powers, especially the US military engagement abroad, he is obliged to exercise in full coordination with Congress. This obligation does not come as much from the constitution as from the practical needs of the defense budget and generally for the implementation of the government program. Also the President is restricted through the War Powers Resolution, by which Congress ensures participation in creating and overseeing the implementation of national security policies. Moreover, the efforts of the legislative (Congress) have contributed to strengthening of the legitimacy of foreign policy and security, for the fact that in most cases the national consensus on vital national interests has been maintained.

On the other hand, there is only this interagency report that makes the US president to be accountable before the national and international security. In fact, the preservation of republican democracy, and for more of the socio-political context and American constitutionalism supported strongly on the principle of separation and balance of powers prevents the presidential power from turning into autocratic power.

\section{References}

Alexander, H., John, J., \& James, M. (2010). The Federalist, The Gideon Edition Edited with an Introduction, Reader's Guide, Constitutional Cross-reference, Index, and Glossary by George W. Carey and James McClellan, Liberty Fund Indianapolis, 2010.

AP® Government and Politics: United States Balance of Power Between Congress and the President, The College Board, 2008.

Black's Law Dictionary, Fourth Edition, West Publishing Company, 1968.

Jon, L. (1947). Two Treatises of Government, New York, 1947.

Law on Emergencies. (Public Law 94-412).

Lois Fisher: The White House Transition Project, Reports 2009-06, Presidential Power In National Security: A Guide To The President-Elect, White House Transition Project.org.

Destler, M. (1986). The Presidency and National Security Organization, in The National Security-Its Theory and Practice, 1945-1960, Edited by Norman A. Graebner, Oxford University Press, New York, 1986.

Mark, R. (2012). The Constitution and Executive Privilege, July 12, 2012.

Nancy, L. B. Executive Secrecy: George W. Bush and Beyond.

Presidential Order. (2007). No.51, issued on 9 May 2007.

Presidential Studies Quarterly. (1999). Center for the Study of the Presidency, 29(4), December 1999.

Public Law 112 - 166 - Presidential Appointment Efficiency And Streamlining Act Of 2011 CRS Report R41872, Presidential Appointments, the Senate's Confirmation Process and Changes Made in the 112th Congress, by Maeve P. Carey.

Public Law 94-412, Sept. 14, 1976.

Robert, Y. S. (2000). Presidential Power, Columbia University Press, New York, 2000.

Theodore, R. (1913). An Autobiography, New York, Macmillan, 1913.

US Constitution.

War Powers Resolutio. (P.L. 93-148).

\section{Copyrights}

Copyright for this article is retained by the author(s), with first publication rights granted to the journal.

This is an open-access article distributed under the terms and conditions of the Creative Commons Attribution license which permits unrestricted use, distribution, and reproduction in any medium, provided the original work is properly cited. 